The late Alvan G. Clark. - Prof. Hale gives a brief obituary notice of the late world-renowned optician, Mr. Alvan Clark (Astrophysical Journal for August), which is accompanied by an excellent illustration showing him at the Yerkes Observa tory with the crown lens of the 40-inch. In this notice Prof. Hale remarks : "It was no small proof of devotion to his work and interest in its successful termination that he should be willing to leave his home after a nearly fatal stroke of apoplexy, and to undertake a journey of over a thousand miles in order to accompany the 40 -inch objective to its destination." We gather, also, that Mr. Clark considered the question of the possibility of constructing an objective still larger than his last great masterpiece, and, although fearing the effect of flexure, he considered it might be possible to still further increase the aperture without endangering the performance of the objective. Mr. Carl Lundin, who has been in the firm for five-and-twenty years, will continue to carry on the business.

\section{A PLEA FOR A BUREAU OF ETHNOLOGY FOR THE BRITISH EMPIRE.}

$A T$ the meeting of the British Association at Liverpool last year, Mr. C. H. Read, of the British Museum, read a paper before the Anthropological Section, which deserves more notice than has been accorded to it. He urged that "what is needed in this country, with its vast colonial possessions, is a Bureau of Ethnology, such as has now existed for some time in the United States. The value of such an institution for our empire can scarcely be estimated. That its tabulated researches would be of the greatest importance to science will not be doubted; but its strongest claim to existence as a national institution is the immense service it would render, first, to the officers governing our distant possessions, and, second, to the Central Government at home, who would thus have in the compass of a modest library a synopsis of the history, manners, customs, and religious beliefs of the innumerable races composing the British Empire. In a word, we should have at hand the means of understanding the motives which influence the peoples with whom we are constantly dealing, and thus be able to avoid the disagreements arising from ignorance of their cherished prejudices and beliefs." He then referred to the Bureau of Ethnology in Washington, which was created with the quick decision of a practical people when they realised that they had at their doors a race that was fated to disappear within a measurable time, and that it was their duty to record the history, beliefs and culture of the vanishing American Indian before the oppertunity had passed away for ever.

Prof. Max Muiller, at the meeting of the British Association which was held at Cardiff in $189 \mathrm{r}$, is reported to have said "Our American friends have perceived that it is a national duty to preserve as much as can still be preserved of the languages and thoughts of the indigenous races who were the earliest dwellers on American soil. They know that the study of what might be called intellectual geology is quite as important as that of terrestrial geology, and that the study of the lower strata contains the key to a right understanding of the higher strata in the growth of the human mind. Coming generations will call us to account for having allowed the old world to vanish without trying to preserve its records. Some years ago I had succeeded in persuading a Secretary of State for the Colonies that it was the duty of the English Government to publish a series of colonial records, containing trustworthy information on the languages, customs, laws, religions and monuments of the races inhabiting the English colonies. Lord Granville saw that such an undertaking was a national duty, and that the necessary funds should be contributed by the various colonies. Think what a magnificent work this would have been! But while the American Government has pushed forward its work, Lord Granville's scheme expired in the pigeon-holes of the Colonial Office. America may well be proud of Major Powell, who would not allow the treasures collected by various scholars and Govern ment officials to moulder and perish."

The splendid series of reports and the collections of ethnological specimens in the National Museum at Washington, attest to the ability with which this department is conducted. The appropriation by Congress for the fiscal year 1891-92 "for the purpose of continuing ethnological researches among the American Indians" was 50,000 dols. During the same year six ethnologists and seven archæologists were on duty in the field, besides the work done in the Bureau in Washington.

NO. 1459 , VOL. 56]
Mr. Read, however, did not propose that in England we should found a Bureau on precisely the lines of the American one. The conditions of the two countries are not sufficiently alike, but the point he urged was: "If the Government of the United States thinks it worth while to be at so much pains, and to incur such an outlay, in order to place on record the history of the one race with which they have to deal, how much more is it the duty of Great Britain to attempt some record of the many vanishing or, at any rate, quickly-changing races within her borders? I would not only say that it is a duty, but I contend that it would be greatly to the interest and profit of England to institute an ethnographic survey of the native races within and upon the borders of her empire. Colonial history is not very ancient-some of it very recent indleed ; but how common it is in the history of almost all our colonies to find skirmish after skirmish with the natives arising from ignorance of the native customs and beliefs on the part of the white man, resulting in much trouble to the latter, and, in far too many cases, in the annihilation of the unfortunate natives. The study of ethnology would not entirely prevent such misunderstandings, but it would tend to remove them more quickly if they should occur. An officer who, possessing other qualifications, applies himself to the systematic study of the peoples around him, so that he can readily enter into their methods of thought, and interpret their actions as well as their words, is, I contend, a more valuable agent than one who merely gives his mind and his time to his strictly official business, and his work should be considered of greater value by his superiors at home." Mr. Read alluded to the attempt in this direction of one of the Governments of India, the Madras Presidency, and the labours of Mr. Man and Mr. Portman in the Andaman Islands, Sir Harry Johnston in Africa, and of Sir William McGregor in New Guinea. He advocated (I) that the reports should be systematised and on a uniform method in an office in London; (2) that such work should be held to be part of the duties of the officer on duty abroad ; and consequently (3) the officer should obtain credit for such work when well done.

The following resolution was referred to the Council of the British Association: "That it is of trgent importance to press upon the Government the necessity of establishing a Bureau of Ethnology for Great Britain, which, by collecting information with regard to the native races within, and on the borders of, the Empire, will prove of immense value to science and to the Government itself." The Council subsequently appointed a Committee consisting of the President (Lord Lister) and General Officers, with Sir John Evans, Sir John Lubbock, Mr. C. H. Read, and Prof. E. B. Tylor. The report of this Committee was presented to the Council of the Associa. tion at the Toronto meeting. It dealt with the urgency, so far as science is concerned, of the need of collection of facts and with the benefit to the Government of these inquiries. Finally it was pointed out that "the collecting of the necessary information for the Bureau could be done with but little expense and with a very small staff only, if the scheme were recognised and forwarded by the Government. The Bureau itself, the central office, would be of necessity in London. The Colonial Office would obviously present some advantages. The British Museum has been suggested, with good reason, and there appears to be no insuperable difficulty if the Trustees are willing to undertake the responsibility of controlling such a department. The staff would not be numerous. A director accustomed to deal with ethnological matter would necessarily direct the conduct of inquiries, and until the material assumed large proportions two or three clerks would probably suffice. If the value of the results were considered to justify it, the increase of the area of operations over the world would probably call for additional assistance after the Bureau had been at work for a few years" The Council resolved that the Trustees of the British Museum be requested to consider whether they could arrange for the proposed Bureau to be established in connection with the Museum and if they are unable to sanction this proposal, that the authorities of the Imperial Institute be requested to undertake its establishment.

The present writer remarked some years ago :- "Such a Bureau would serve as a great stimulus to those who are interested in native races, but who require encouragement and direction. There can be little doubt that an immense number of isolated observations are lost for the lack of a suitable depository, the observers being fully aware that these are too casual to be of 
much value; when accumulated, however, the case is very different. Were it known that a record of any obscure or rarely observed custom would be duly filed and classified and be readily available to any one who was studying native folk-lore, the probability is that many memoranda which otherwise would be lost would find their way to the Bureau. It cannot be ton often or too strongly insisted upon, that now is the time for the collection of all anthropological data in every department of that far-reaching science. To many, results alone are interesting, and there is too frequently a danger to generalise from imperfect data. Posterity will have plenty of time in which to generalise and theorise, but it will have scarcely any opportunity for recording new facts. This century has been one of most rapid transition. The apathy of our predecessors has lost to us an immense amount of information : let not this reproach be applied to us by our descendants."

A decade ago, that distinguished Indian officer Major R. C. Temple wrote: "I have no hesitation in saying that to us Englishmen such studies are not only practical, but they are in some respects of the first importance. The practices and beliefs included under the general head of folk-lore make up the daily life of the natives of our great dependency, control their feelings, and underlie many of their actions. We foreigners cannot hope to understand them rightly unless we deeply study them, and it must be rememhered that close acquaintance and a right understanding beget sympathy, and sympathy begets good government; and who is there to say that a scientific study which promotes this, and, indeed, to some extent renders it possible, is not a practical one?"

A. C. IIADDON.

\section{INSECTS AND YEASTS.}

IN the Portici Laboratory for Agricultural Chemistry, Dr. Amedeo Berlese has been making interesting investigations on the manner in which some insects-ants and flies especially-contribute to the diffusion, preservation and multiplication of alcoholic ferments.

It had been formerly observed by Dr. Berlese that on the trunks, both of fruit and forest trees, hidden in the fissures of the bark, the cells of alcoholic yeasts (Saccharomyces apiculatus and Saccharomyces ellipsoideus) are commonly found. It was natural to suspect that ants, which are constantly travelling up and down trunks and branches, and perhaps also flies, should be among the chief agents in disseminating yeast cells on trees. Dr. Berlese had also observed that these cells are often more numerous on the sunny side of the trees, where insects, especially flies, are likely to linger.

The first series of experiments was to show that ants, starting from an infected soil, and being themselves infected with yeast cells, carry them for a distance up stems and branches, infecting the fruits which they visit, and thence travelling further may carry on the yeast-infection into a sterilised soil.

The apparatus used was very simple (Fig. I). Inside a large glass jar A, well closed and carefully sterilised, a bunch of grapes was hung, after due sterilisation by successive washing and immersion in carbon disulphide and boiling water. The jar containing the grapes communicated by means of two long glass tubes (about $1 \cdot 30 \mathrm{~m}$. each) with a glass bottle on each side. These long tubes and the bottles were also carefully sttrilised, and connected, by means of corks, so as to form, together with the central jar, a closed system, into which, how. ever, air could penetrate after filtering through sterilised cotton wool. Fourteen of these combinations were prepared, into each of which, in one of the side bottles B, non-sterilised substances were introduced, probably containing yeast cells, such as soil, bark of vines, bark of vine-poles and of oak-trees. In the second side bottle c, the same substances were introduced, but after careful sterilisation. Inside the long tubes were put slender vine branches connecting the substances in the side bottles $\mathrm{B}$ and $\mathrm{C}$ with the grapes in the central jar A. These vine branches, previously sterilised, were the paths along which the ants were to travel on their way from the infected material in $B$ to the grapes in $\mathrm{A}$, and thence onwards to the sterilised material in c. Before introducing the insects it was verified that each apparatus was internally sterile. Some apparatus were left without insects during all the time of the experiments for more

1 Rapporti fra la Vite ed i Saccaromiceti. Ricerche sui mezzi di trasporto dei Fermenti alcoolici. Amedeo Berlese. Rivista di Patologia
Vegetale e Zimologia, 1897 .

NO. I 459, voL. 56] than two months, in order to show that where no insect had been introduced the grapes remained sterile, bearing on their surface neither moulds, nor yeasts, nor bacteria.

Large numbers of ants were collected from the trunks of trees. One species-the Cremastogaster scutellaris - was preferred, because it lives in trees, and is very common on vines and vine-poles. The ants were collected with due precaution into sterilised glass vessels, and thence introduced into the bottle $\mathrm{B}$ of each apparatus, in numbers varying from a minimum of about 100 to a maximum of about 5000 . In the bottle $\mathrm{B}$ the ants remained for a few days, then gradually and guardedly ad. vanced up the sterilised branches, congregating and halting at stations on their upward way in the long tubes ; generally about two days passed before the first ants appeared on the sterilised grapes in $\mathrm{A}$; thence they passed down the second tube into the bottle $\mathrm{c}$. In this way, starting from $\mathrm{B}$, the most adventurous of the ants which reached $\mathrm{c}$, had travelled a distance of $3.20 \mathrm{~m}$., about equal to the actual height of many vines from the soil, over which ants must travel when they climb up to visit the grapes. The ants used in these experiments suffered probably from want of ventilation; they attacked the corks in efforts to escape, and congregated in great numbers near the cotton wool through which the outer air filtered. Many, however, visited the grapes in search of food, biting the surface of the berries, or absorbing the juice where these had been purposely punctured. In one apparatus where the grapes were unripe, their acid juice proved rapidly poisonous to the ants: an interesting observation, for it gives evidence in favour of the protective character

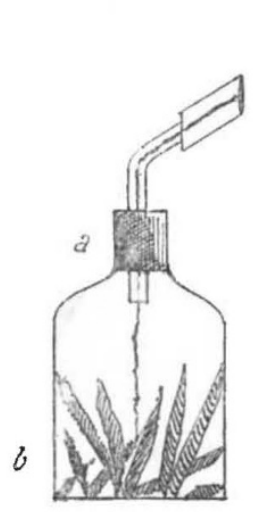

B

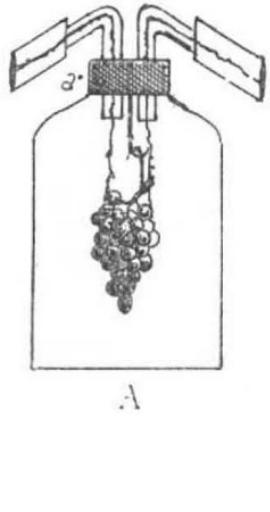

FIG. I

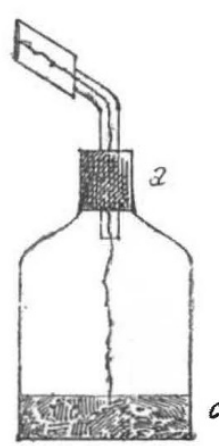

$\mathrm{C}$ of the acids existing in fruit juices before maturation. A small number of ants reached the bottle c. After ten or twelve days most of the ants were dead, and the experiments were ended. The grapes and the materials in $\mathrm{C}$, that had been previously sterilised, were now separately tested to see if through the agency of the ants they had been infected with yeasts. The grapes were removed from the jars with due caution to prevent air-infection, and after shaking off gently all insects still adhering to the fruit; whole berries or small portions of the stalks of the bunches were dropped, without delay, into test-tubes containing sterilised grape-must; and the plugged test-tubes were then left in the thermostat for several days, at a temperature favourable to alcoholic fermentation.

The results obtained are remarkable. In the ten experiments in which ants were introduced, the infection of the grapes in A, and of the material in $\mathrm{c}$, with yeasts and moulds was evident; but varied chiefly according to the various nature of the places from which the ants originally came, and also with the nature of the non-sterilised material in $\mathrm{B}$. When the ants came from a vineyard, and the material in $\mathrm{B}$ was ordinary soil or bark of vines or of vine-poles, the germs conveyed to the grapes in $\mathrm{A}$, and to the sterilised material in C, were chiefly moulds together with Saccharomyces apiculatus and ellipsoideus; S. apiculatus was far more abundant than ellipsoideus. In one case, when B contained oak bark and the ants had been collected on oak trees, the infection of the grapes and of the material in $\mathrm{C}$ showed abundance of Saccharomyces apiculatus, with some $S$. ellipsoideus and $S$. pastorianus. When the ants and the bark in $\mathrm{B}$ came from olive-trees no yeasts were observed in the 